ФАСИЛІТАЦІЙНА КОМПЕТЕНТНІСТЬ МАЙБУТНЬОГО ПЕДАГОГА: СУТНІСТЬ I СТРУКТУРА

\title{
FACILITATIVE COMPETENCY OF A FUTURE TEACHER: ESSENCE AND STRUCTURE
}

\begin{abstract}
Актуальність цієї статті зумовлена соціально-економічними, інноваційно-освітніми трансорормаціями в житті України, а також глобалізаційними процесами, орієнтованими на інтеграцію нашої держави зі світовою спільнотою, які об'єктивно зумовлюють зміни векторів розвитку усіх ланок освіти в напрямі людиноцентризму, розгляду особистості здобувача освіти як вищої цінності. y cmammi розглянуто френомен фрасилітації у межах реалізації компетентнісного підходу. На основі аналізу семантичних складників, якими є «фрасилітація» та «компетентність», обгрунтовано поняття «фрасилітаційної компетентності». Представлено авторську дефрініцію фрасилітаційної компетентності майбутнього педагога як його інтегровану характеристику, що синтезує його провідні профресійно-особистісні якості, які забезпечують готовність до фрасилітації суб'єктів освітнього процесу. Визначено структуру фасилітаційної компетентності майбутнього педагога, яка містить мотиваційно-аксіологічний, когнітивний, праксіологічний компоненти, що мають аспект перцепції, інтеракції, комунікації.

З'ясовано, що мотиваційно-аксіологічний компонент пов'язаний із фасилітаційною позичією, яка передбачає людиночентровану установку, ставлення до здобувачів освіти як до найвищої цінності, відкритість, доброзичливість, толерантність, тактовність, емпатійність; когнітивний компонент містить знання про сутність фрасилітаційної взаємодії та спілкування, вікові й індивідуальні особливості суб'єктів освіти; праксіологічний компонент представлений перцептивними, проектувально-конструктивними, комунікативними, рефрлексивно-аналітичними вміннями. Визначено, що подальшого студіювання потребує аспект етапності формування фрасилітаційної компетентності майбутнього педагога в процесі професійної підготовки у $3 В О$.

Ключові слова: компетентнісний підхід, компетенція, компетентність, фрасилітаційна компетентність, структура фрасилітаційної компетентності майбутнього педагога.
\end{abstract}

The relevance of this article is conditioned by socio-economic, innovative and educational transformations in Ukraine's life, as well as by globalization processes focused on the integration of our state with the world community which objectively determine changes in the vectors of development of education at all levels in the direction of human-centrism, the view of the personality of an applicant for education as the highest value.

The article deals with the phenomenon of facilitation within the framework of the competence-based approach. On the basis of the analysis of semantic components which are 'facilitation" and "competency', the concept of facilitative competency has been substantiated. The author's definition of facilitative competency of a future teacher as an integrated characteristic of a future teacher has been presented, which synthesizes his leading professional and personal qualities ensuring the readiness to facilitate the subjects of the educational process. The structure of the facilitative competency of a future teacher has been determined which contains motivational-axiological, cognitive and praxeological components, which in turn have the aspect of perception, interaction and communication.

It has been found out that the motivationalaxiological component is associated with a facilitative position, which provides for a humancentered mindset, attitude towards applicants for education as to the highest value, openness, benevolence, tolerance, tactfulness, empathy; the cognitive component contains knowledge about the essence of facilitative interaction and communication, age and individual characteristics of subjects of education; the praxeological component is represented by perceptual, design-constructive, communicativeempathic and reflexive-analytical skills. It has been determined that further study requires the aspect of the phased formation of the facilitative competency of a future teacher in the process of professional training at a higher educational establishment.

Key words: competence-based approach, competence, competency, facilitative competency, structure of facilitative competency of a future teacher.
Постановка проблеми в загальному вигляді. Глобалізаційні та євроінтеграційні виміри сучасного суспільства, стратегічні позиції педагогіки партнерства, задекларовані в концепції Нової української школи (2017 рік), пов'язані з ідеями рівності, діалогу, співпраці. Вони детермінують потребу у фахівцях, здатних комунікувати, взаємодіяти з іншими людьми, спільно вирішувати певні проблеми, працювати в команді, тобто бути готовими до фрасилітативної підтримки суб'єктів різних ланок освіти в Україні.

3 огляду на людиноцентровані й компетентнісні орієнтири сучасної освіти, постає необхідність у фрормуванні такої суттєвої профресійно-особистісної якості майбутнього педагога як фрасилітаційна компетентність, яка передбачає реалізацію його супровідної, підтримувальної, допоміжної, партнерської функції в освітньому процесі. Зазначені об'єктивні обставини загострюють актуальність проблеми визначення сутності й структури фрасилітаційної компетентності майбутнього педагога як цільових орієнтирів професійної підготовки майбутнього педагога у закладі вищої освіти (далі - 3ВО).

Актуальність обраної проблеми посилюється наявними в сучасній системі освіти суперечностями 
між її оновленими цілями, зорієнтованими на гуманізацію освітнього процесу та визнання особистості найвищою цінністю і здебільшого низьким рівнем готовності певної кількості педагогів до фасилітаційної взаємодії зі здобувачами освіти.

Аналіз останніх досліджень і публікацій. Концептуалізація френомену фасилітації відбулася у студіях М. Бердяєва, М. Бахтіна, Г. Ващенко, Г. Сковороди. Однак наукового статусу фрасилітація набула у працях відомого гуманістичного психолога К. Роджерса.

Поняттєве поле френомену фрасилітації представлено такими варіативами: соціальна фрасилітація (Л. Тимоніна, В. Фрейнберг); педагогічна фрасилітація (І. Авідєєва, О. Галіціан, О. Димова, Р. Димухаметов, І. Жижина); фрасилітуюча позиція (О. Фісун); фрасилятивність особистості (М. Казанджи); фрасилітаційне спілкування (О. Врубльовська, В. Суміна); фрасилітація як важливий чинник ефрективного спілкування у контексті самоактуалізації особистості (А. Адлер, Г. Балл, Е. Бернс, М. Еріксон, А. Маслоу, К. Ясперс); фрасилітаційна взаємодія (І. Прокопенко, Р. Шаповал).

Низка досліджень присвячена розгляду пізнавальної, комунікативної, діагностико-прогностичної фрункції фрасилітації (Т. Лозова); дидактичнопрофесійній, нормативній (О. Жерновникова); захисній фрункції (Л. Перминова). Процес фрасилітативного розвитку особистості висвітлено у дослідженнях Н. Завацької, І. Ісаєва, 3. Ковальчук, В. Слободчикова.

Сучасний науковий дискурс щодо феномену компетентності представлений дослідженнями фундаментальних засад компетентнісного підходу (О. Субетто, І. Байденко, І. Зимня, Ю. Татур), питань впровадження компетентнісного підходу у систему освіти (Н. Бібік, С. Вітвицька, О. Дубасенюк, О. Локшина, О. Овчарук, О. Пометун, О. Савченко). Феномен фрасилітаційної компетентності майбутніх вчителів гуманітарних спеціальностей порушено у дисертації О. Фокши. Фасилітаційна компетентність керівника закладу освіти стала предметом дослідження Т. Сорочан.

Виділення не вирішених раніше частин загальної проблеми. Стратегічні орієнтири сучасної вітчизняної освіти, пов'язані з її людиноцентрованими, суб'єктно-діяльнісними вимірами, реалізацією принципів педагогіки партнерства, ідей компетентнісної парадигми освіти, зумовлюють зміну статусу педагога в напрямі гуманізації стосунків зі здобувачами освіти, оволодіння стилем міжособистісних відносин, заснованих на взаєморозумінні, співробітництві й емпатії, що акумулюються у фасилітаційній компетентності. За досить широкої дослідженості проблеми фрасилітації аспект сутності та структури фрасилітаційної компетентності майбутнього педагога залишився поза увагою науковців, тому він потребує наукової розвідки.
Мета статті - визначити сутність і структуру фрасилітаційної компетентності майбутнього педагога.

Виклад основного матеріалу. Розглянемо базове поняття дослідження «фрасилітаційна компетентність майбутнього педагога» на основі аналізу його семантичних складників, якими $є$ «фрасилітація» та «компетентність».

Етимологія поняття «фрасилітація» пов'язана 3 англійським "facilitate" (у перекладі «допомога, полегшення, сприяння»). У педагогічну теорію термін «фрасилітація» ввів К. Роджерс. Відомий психотерапевт і педагог виділив три основні установки вчителя-фрасилітатора:

1) «істинність» та «відкритість»;

2) «прийняття» і «довіра»;

3) «емпатичне розуміння» [9].

К. Роджерс пов'язував фрасилітацію 3 відкритістю власним думкам і переживанням, здатністю чесно, щиро, відкрито транслювати їх своїм вихованцям; 3 особистісною впевненістю педагога в можливостях і здібностях учнів; із баченням вчителем внутрішнього світу та поведінки кожного учня 3 його внутрішньої сторони.

Педагогічний контекст фрасилітації (О. Димова, І. Жижина) передбачає організацію певного типу міжособистісних відносин, які забезпечують створення ефективних умов для саморозвитку й самореалізації особистості, спонукають її до реалізації зусиль для розкриття власних внутрішніх потенцій. Суттєвими ознаками таких взаємовідносин є взаємопізнання, взаєморозуміння, узгодженість спільних дій і взаємовплив між всіма учасниками [2; 3].

$€$ доцільним трактування френомену фрасилітації (О. Фокша), пов'язане з такими його аспектами:

- взаємовплив людей, зумовлений соціальними контактами, що підвищує їхню активність, сприяє активізації психічних процесів, поліпшенню самопочуття;

- специфічний вид спілкування, який передбачає полегшення взаємодії усіх суб'єктів освітнього процесу;

- спосіб допомоги групі в пошуку шляхів виявлення й розв'язання проблем [8, с. 8].

Беручи до уваги окреслені наукові позиції, будемо тлумачити педагогічну фрасилітацію як процес взаємодії, спілкування між суб'єктами освітнього процесу на засадах людиноцентризму, міжсуб'єктності, толерантності й емпатії, що сприяє особистісному саморозвитку та їх конструктивній взаємодії.

Феномен фрасилітації ми досліджуємо в межах реалізації компетентнісного підходу, який є спрямованістю освіти на розвиток особистості в результаті фрормування в неї таких особистісних якостей як компетентність засобами розв'язання профресійних і соціальних завдань в освіті (І. Зимня) [4]; 
на фрормування й розвиток ключових (базових, основних) і предметних компетентностей особистості (О. Пометун) [6].

Ґрунтовними поняттями компетентнісного підходу $€$ категорії «компетенція» та «компетентність», які ми трактуємо так:

- компетенція - це задана вимога, норма освітньої підготовки; це об'єктивна сукупність певних знань у будь-якій галузі; це змістовна потенційна характеристика; коло повноважень певної організації, установи або особистості;

- компетентність є суб'єктивною, актуальною, особистісною характеристикою; це реально сорормовані особистісні якості та досвід діяльності особистості.

Поняття «фрасилітативна компетентність» у працях Т. Сорочан використано у форматі складника управлінської компетентності керівників закладів освіти, який авторка визначає як здатність керівника бути провідником змін в освіті, мотивувати учасників освітнього процесу до особистісного розвитку, забезпечувати для цього необхідні умови [7].

О. Фокша обґрунтовує конструкт «фрасилітативна компетентність майбутнього вчителя гуманітарних спеціальностей», який трактує як «інтегративний динамічний комплекс індивідуально-особистісних і професійно-діяльнісних якостей педагога, який характеризуються здатністю вибудовувати фрасилітаційну взаємодію 3 усіма суб'єктами освітнього процесу з урахуванням розвивального потенціалу гуманітарних дисциплін» [8, c. 8].

На нашу думку, фрасилітативна компетентність - це інтегрована характеристика майбутнього педагога, яка синтезує його провідні професійно-особистісні якості, що забезпечують готовність до фрасилітації суб'єктів освітнього процесу.

Представимо структуру фрасилітативної компетентності. Відомий підхід О. Фокши, яка виокремлює гносеологічний, праксеологічний, аксіологічний компоненти фрасилітаційної компетентності [8]. Наше трактування структури фрасилітативної компетентності базується на двох позиціях. Перша пов'язана зі структурно-діяльнісною ознакою, яка ґрунтується на психологічній структурі діяльності, визначеній О. Леонтьєвим як єдність і взаємодія категорій потреби, мети, мотивів, дій (операцій) [5], а також на підході О. Бодальова [1], відповідно до якого у структурі фрасилітативної компетентності доцільно виокремити дві групи особистісних утворень: ті, що постають як спонукачі діяльності та поведінки, ті, що складають їх виконавчий компонент. У цьому контексті структура фрасилітаційної компетентності майбутнього педагога представлена мотиваційно-аксіологічним, когнітивним, праксіологічним компонентами. Тобто спонукаль- ним складником фрасилітаційної компетентності є їі мотиваційно-аксіологічний компонент; виконавчим - когнітивний і праксіологічний компоненти.

Основою другої позиції $є$ тлумачення фрасилітації як сукупності фрасилітаційної позиції, фрасилітаційної взаємодії, фрасилітаційного спілкування. Відповідно до цього підходу структура фрасилітаційної компетентності містить аспекти перцепції, інтеракції, комунікації.

Отже, обґрунтована у дослідженні структура фасилітаційної компетентності є синтезом окреслених наукових позицій. Підтвердженням цього $€$ фракт зв'язку мотиваційно-аксіологічного, когнітивного, праксіологічного компонентів фрасилітаційної компетентності з механізмами перцепції, комунікації та інтеракції.

Зупинимося детальніше на розгляді певних структурних складників рефлексивної компетентності майбутнього вчителя початкової школи.

Мотиваційно-аксіологічний компонент досліджуваного нами френомену пов'язаний із фрасилітаційною позицією майбутнього педагога, яка відбиває професійні мотиви й потреби, установки педагога на взаємодію, співпрацю й спілкування на засадах партнерства й міжсуб'єктності зі здобувачами освіти, ціннісне ставлення до них на засадах відкритості, доброзичливості, толерантності, тактовності, емпатійності.

Когнітивний компонент - система знань, які є теоретичною базою для фасилітаційної компетентності. Ми їх визначаємо як систему понять і уявлень просутністьімеханізмифрасилітації, віковійіндивідуальні особливості здобувачів освіти, про принципи й методи організації фрасилітаційного спілкування і взаємодії.

Праксіологічний компонент. Цей складник фрасилітаційної компетентності представлений системою умінь, серед яких виокремлюються перцептивні вміння (вміння адекватно сприймати й розуміти партнерів по спілкуванню); проектувально-конструктивні (вміння організувати командну роботу, надавати педагогічну підтримку й допомогу); комунікативні вміння (вміння організувати партнерські стосунки із суб'єктами освіти, встановлювати 3 ними зворотній зв'язок); рефлексивно-аналітичні вміння (вміння, пов'язані із самопізнанням і розумінням іншого, самоінтерпретацією та інтерпретацією іншого, вміння бачити себе «очима партнера»).

Висновки. На підставі викладеного зазначимо, що фрасилітація як процес взаємодії, спілкування між суб'єктами освітнього процесу на засадах людиноцентризму, міжсуб'єктності, толерантності й емпатії є суттєвим складником профресійної діяльності, а фрасилітаційна компетентність як інтегрована характеристика майбутнього педагога, що синтезує його провідні професійноособистісні якості, які забезпечують готовність до 
фрасилітації суб'єктів освітнього процесу, є важливою професійно-особистісною характеристикою сучасного педагога.

Структура фрасилітаційної компетентності майбутнього педагога містить мотиваційно-аксіологічний, когнітивний, праксіологічний компоненти, які мають аспект перцепції, інтеракції, комунікації. При цьому мотиваційно-аксіологічний компонент пов'язаний із фрасилітаційною позицією, яка передбачає людиноцентровану установку, ставлення до здобувачів освіти як до найвищої цінності, відкритість, доброзичливість, толерантність, тактовність, емпатійність; когнітивний компонент містить знання про сутність фрасилітативної взаємодії та спілкування, вікові й індивідуальні особливості суб'єктів освіти; праксіологічний компонент представлений перцептивними, проектувально-конструктивними, комунікативними, рефлексивно-аналітичними вміннями.

Подальшого студіювання потребує аспект етапності фрормування фрасилітаційної компетентності майбутнього педагога в процесі професійної підготовки у 3 ВО.

\section{БІБЛІОГРАФІЧНИЙ СПИСОК:}

1. Бодалев А.А. Психология личности. М. : МГУ, 1988. 188 с.
2. Димова О.И. Педагогические условия развития способности к фрасилитирующему воздействию у будущих учителей : дис. канд. пед. наук. Хабаровск : Комсомольский-на-Амуре государственный педагогический университет, 2002. 199 с.

3. Жижина И.В. Психологические особенности развития фрасилитации педагога : дис. канд. псих. наук. Екатеринбург, 2000. 186 с.

4. Зимняя Н.А. Ключевые компетентности как результативно-целевая основа компетентностного подхода в образовании. М. : ИЦ ПКПС, 2004. 220 с.

5. Леонтьев А.Н. Деятельность. Сознание. Личность. М. : Политиздат, 1977. 304 с.

6. Пометун О. Запровадження компетентнісного підходу - перспективний напрям розвитку сучасної освіти. URL: http://visnyk.iatp.org.ua.

7. Сорочан Т.М. Розвиток професіоналізму управлінської діяльності керівників загальноосвітніх навчальних закладів у системі післядипломної педагогічної освіти [Текст] : дис. д-ра пед. наук: 13.00.04. Луганський національний педагогічний ун-т ім. Тараса Шевченка. Луганськ, 2005. 478 с.

8. Фокша О.М. Педагогічні умови формування фрасилітаційної компетентності майбутніх вчителів гуманітарних спеціальностей у професійній підготовці [Текст] : автореф. дис. канд. пед. наук: 13.00.04. Держ. закл. «Південноукр. нац. пед. ун-т ім. К.Д. Ушинського». Одеса, 2019. 21 с.

9. Rogers C. Freedom to learn for the 80's. Columbus - Toronto - London - Sydney : Ch. E. Merrill Publ. Company, A Bell \& Howell Company, 1983. 312 p. 